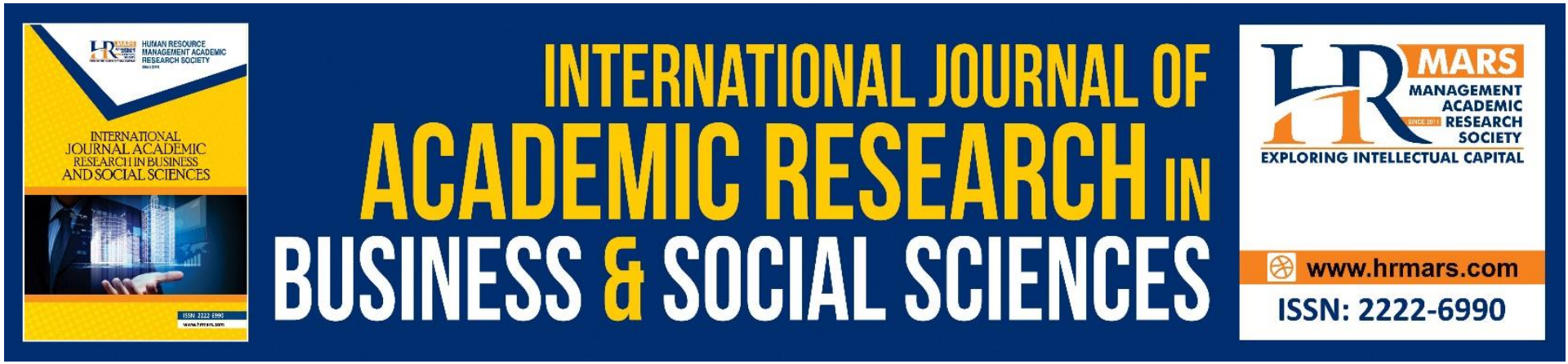

\title{
Determinants of Social Entrepreneur Intention and Behavior among Online Distance Learning Students in Malaysia
}

\section{Zahir Osman}

To Link this Article: http://dx.doi.org/10.6007/IJARBSS/v10-i11/9075

DOI:10.6007/IJARBSS/v10-i11/9075

Received: 21 September 2020, Revised: 24 October 2020, Accepted: 19 November 2020

Published Online: 29 November 2020

In-Text Citation: (Osman, 2020)

To Cite this Article: Osman, Z. (2020). Determinants of Social Entrepreneur Intention and Behavior among Online Distance Learning Students in Malaysia. International Journal of Academic Research in Business and Social Sciences, 10(11), 1496-1506.

Copyright: @ 2020 The Author(s)

Published by Human Resource Management Academic Research Society (www.hrmars.com) This article is published under the Creative Commons Attribution (CC BY 4.0) license. Anyone may reproduce, distribute, translate and create derivative works of this article (for both commercial and non-commercial purposes), subject to full attribution to the original publication and authors. The full terms of this license may be seen at: http://creativecommons.org/licences/by/4.0/legalcode

Vol. 10, No. 11, 2020, Pg. 1496 - 1506

Full Terms \& Conditions of access and use can be found at http://hrmars.com/index.php/pages/detail/publication-ethics 


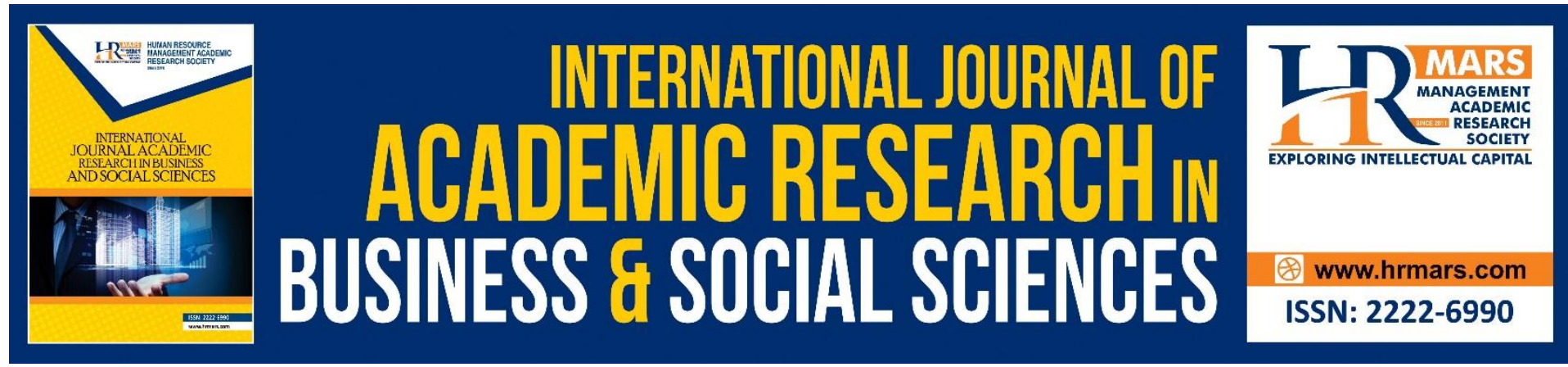

\title{
Determinants of Social Entrepreneur Intention and Behavior among Online Distance Learning Students in Malaysia
}

\author{
Zahir Osman \\ Cluster of Business of Management, Open University Malaysia, Malaysia
}

\begin{abstract}
This study is aiming to evaluate of attitude, self-efficacy, social norms and perceived behavioral control on intention and direct effect of intention on behavior to become social entrepreneur among students in online distance learning (ODL) higher institutions in Malaysia. This study adopted Partial Least Square (PLS) procedure on data collected from a survey that yielded 227 usable questionnaires. To evaluate the casual relationships among attitude, social norms, perceived behavioral control, intention and behavior, the Structural Equation Model (SEM) technique was utilized. The statistical results confirmed that attitude, social norms and perceived behavioral control have a positive and significant influence on intention and intention has a positive and significant influence on behavior among students in Malaysian ODL higher institutions. The findings suggest that ODL institutions should give greater emphasis on strengthening attitude, social norms, perceived behavioral control, and intention to ensure their ODL students have strong behavior to become online entrepreneur. The study thus offered new insights into the relationship attitude, social norms, perceived behavioral control, intention and behavior this relationship for students in online distance learning social entrepreneurial intention.
\end{abstract}

Keywords: Attitude, Social Norms, Perceived Behavioral Control, Intention And Behavior, Online Distance Learning.

\section{Introduction}

Social entrepreneurship is growing and has become an up-and-coming trend among the people, not only in Malaysia but also throughout the world. As Barendsen \& Gardner (2004) said, social entrepreneurship is not something new. Social entrepreneurship is where entrepreneurs are going to help society and the environment by starting the new business venture. Abu Sivan (2012) said that the most important thing for social entrepreneurs is to fulfill their social duties. Many organizations use this concept with different formats, goals, and beliefs. In Malaysia, the number of social entrepreneurs is still lacking in any other developed country. Moreover, Malaysian social institutions have no specific legal structure compared to the United States. In Malaysia, the government has made an initiative to encourage young people to become social entrepreneurs by introducing special courses on social entrepreneurship at the level of higher education. Moreover, more and more programs 
are attracting young people to help the community. Besides, young people will recognize the importance of becoming a social entrepreneur and taking more responsibility for society (Zainol et al., 2014). Although social entrepreneurship is becoming more important currently compared to other businesses and not much study has been done in Malaysia and also there is lacking data to formulate the strategy to strengthen social entrepreneurship (Dacanay, 2005). In Malaysia, there is no legal requirement for social projects, such as some states in the United States (Morrison and Forster, 2016). In Malaysia, the Global Center for Innovation and Creativity in Malaysia which is known as MAGIC is one of the organizations that

provide support for social entrepreneurs. Social Project Blueprint 2015-2018 which was officiated by Malaysian Prime Minister, is a three-year strategic plan for social institution development by the formation of MAGIC to provide Malaysia's socio-economic growth by $\$$ 20 million Malaysian funding (Digital News Asia, 2015). Also, the Malaysian Alliance Social Fund (SEA) is under the MAGIC umbrella, which has its development program that facilitates social entrepreneurs and industry experts' communication. This idea maintains the potential development of Malaysian social entrepreneurs. With this assistance and funding, it will attract more new young entrepreneurs to take part in future social activities (Yeoh, 2015). According to Roberts (2005), there are various programs; training and education initiatives have been implemented to bring the country to the greater heights. However, magic is focused not only on the social entrepreneur but also on all types of business in the country (Magic, 2018; Zainol, Daud, Abdullah \& Yaacob, 2014.). Young people, especially Malaysian students, are still lacking knowledge of social entrepreneurship. The scenario is linked to a lack of awareness of this phenomenon, lack of data, and lack of social entrepreneurship training programs that support the development of social entrepreneurship. There is still an absence of social entrepreneurs' reviews in Malaysia. However, many studies have found but studies have found that many young Malaysians are motivated to become social entrepreneurs (Digital News Asia, 2015). Omorede (2014) suggested that motivating elements compel people to take part in social entrepreneurship, but they are frequently failed to be noticed. Therefore, there is a need for new research to be done to get more insight into the reason social entrepreneurs are looking beyond the challenges. Furthermore, Kruger, Schulte \& Stamp, 2008) have revealed a lack of knowledge of the factors influencing the intentions and activities of social entrepreneurs. Therefore, this study attempts to assess the factors influencing intention to become a social entrepreneur among online distance learning students in Malaysia.

\section{Literature Review}

Underpinning Theory

According to Shane \& Venkataraman (2000), entrepreneurship can be considered as a process of discovering, creating, evaluating, and exploiting opportunities that need preparation to make the opportunity realizable (Krueger \& Brazeal, 1994; Cooper \& Park, 2008). Because of this perspective, the behavior is best predicted by entrepreneurial intention. The reason is a person who inclines to become an entrepreneur is caused by intentionally planned behavior (Liñán. Rodríguez \& Rueda, 2011). Theory of reason action which is commonly known as intention-based theory discusses the intention through a formulation of subjective norm and attitude as the factors that affect behavior. The theory of planned behavior is originated from the theory of reason action and having perceived behavioral control as a new variable in the model (Ajzen, 1991). The theory of planned behavior (TPB) which used to forecast and 
describe behavior in a certain context (Ajzen, 1991) is the common theory used in the various discipline (Renko, Kroeck, \& Bullough, 2012). Someone who wants to become an entrepreneur is considered to be conscious and intention is deemed to be in a cognitive situation (Renko, Kroeck, \& Bullough, 2012). According to Liñán (2008), besides personality traits and demographic studies, cognitive aspect has more valuable information with regards to entrepreneurial behavior due to its closer factor to the behavior (Liñán. Rodríguez \& Rueda, 2011; Kautonen, Van Gelderen \& Tornikoski, 2013). Previous researches results show that the theory of planned behavior is practical and can be used in entrepreneurship research (Liñán \& Chen, 2009).

\section{Attitude}

Attitude is one of the crucial elements of a person to success as an entrepreneur (Mohd Salleh et al. 2005), Sudipa and Damodharan, 2012). Therefore, generally, there will be a strong intention to perform the behavior of the person if his or her attitude is more favorable (Ajzen, 1991). Mutsau (2016) mentioned students will have a strong intention to become entrepreneurs upon completion of their study if they have a positive attitude towards the behavior. Likewise, Remeikiene, Startiene \& Dumciuviene (2013) suggested that attitude influence entrepreneurship was an important element to drive the students' intention to become an entrepreneur when they conducted their study in Lithuania. Similarly, Ferreira, Raposo, Rodrigues, Dinis, \& Paço (2012) revealed that personal attitude has a positive and significant impact on the attitude to become an entrepreneur when did their study on the students in Portugal. It is further confirmed by Peng, Lu \& Kang (2012) who also found that entrepreneurial intention among the students of the university in their study was strongly influenced by entrepreneurial attitude.

\section{Subjective Norm}

Subjective norms are one of the important criteria in influencing entrepreneurial intention and it represents the view of an individual who influenced by another person. Wedayanti \& Giantari (2016), suggested that subjective norms are important opinion or advice that a person gives to another person whether to act or not to act with specific behaviors and motivation go along with a readiness to do or not to do a certain important thing. According to Liñán et al.,(2011), subjective norms are used as a tool to gauge social pressure that will lead to becoming an entrepreneur. TBP defines subjective norms as an individual important opinion or view before a person acts. Previous studies have revealed that subjective norms strongly influence individual behaviors, particularly when involve intention and attitudes. According to Ajzen (2015), concerning entrepreneurial activities, before becoming an entrepreneur, he or she will be influenced by another person who is deemed to be very important. A strong external view about becoming an entrepreneur will influence and direct the individual to go along with that pressure.

\section{Perceived Behavioral Control}

According to Armitage and Conner (2001), perceived behavioral control (PBC) deemed to be one of the factors that affect the control actual level. To be precise, PBC is referred to as a personal belief about his or her capability to perform a certain duty. Ajzen and Thomas (1986) state that PBC covers the assessment target action ability to do a certain thing. Liñan and Chen (2009) describe PBC as the easiness or difficulty to become an entrepreneur. PBC is a very important variable in the process to create new business exist in its projecting capacity, 
as it mirrors the view that a person will have the ability to manage the behavior (Ajzen, 2002; Liñán, 2008)

\section{Actual Behavior}

As mentioned by Ajzen (1986), behavioral intention is influenced by attitude, subjective norm, and perceived behavior control. A solid connection between behavioral intention and actual behavior performance is depending on the degree where a person has total control to decide to perform or not the behavior (Ajzen, 1986), Intrusion strategy that particularly strengthens antecedents of or reducing entrepreneurial behaviors are inclined to cause continuous behavior alteration than those that not take into account attitude, subjective norm and perceived behavioral control. By focusing on the factors of attitude, subjective norm, and perceived behavioral control that affect the behavior intention, it will not only produce continuous behavior change but also provide a framework to assess the intervention effect.

The following hypotheses are proposed after the development of the conceptual of the study:

$H 1$ : There is a positive and significant influence of attitude on the intention to become a social entrepreneur among ODL students in Malaysia.

$H 2$ : There is a positive and significant influence of social norms on the intention to become a social entrepreneur among ODL students in Malaysia.

H3: There is a positive and significant influence of perceived behavioral control on the intention to become social entrepreneurs among ODL students in Malaysia.

H4: There is a positive and significant influence of intention on behavior to become social entrepreneur among ODL students in Malaysia.

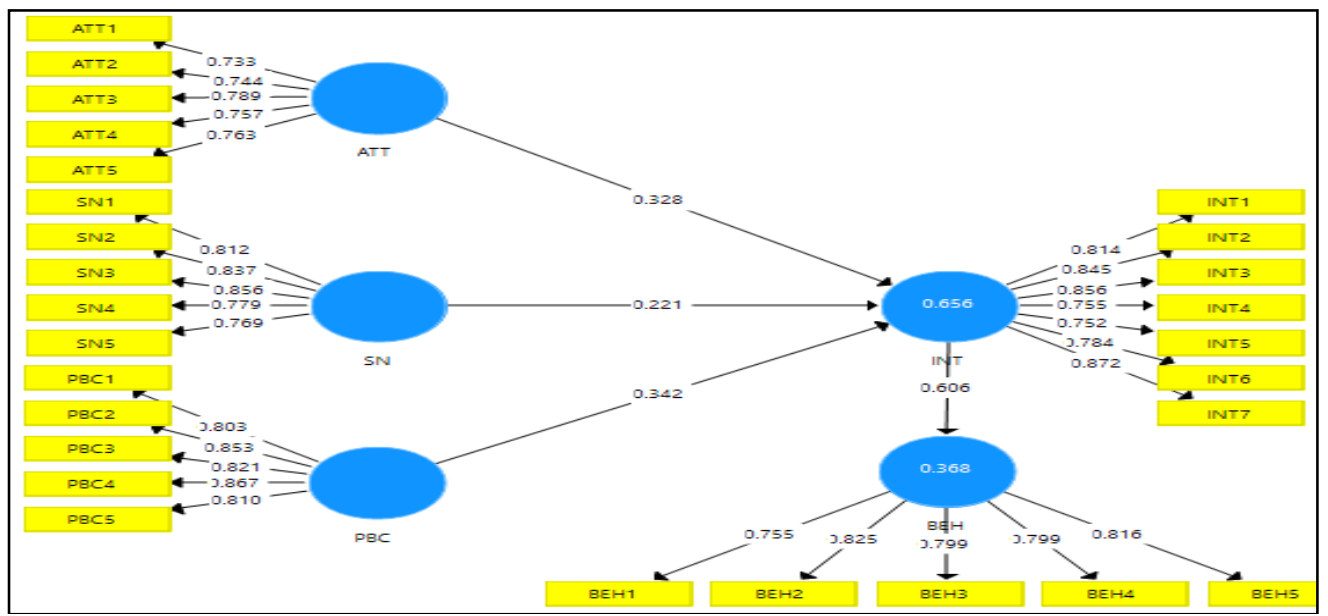

Figure 1: Research Model

\section{Methodology}

Malaysian online distance learning higher institutions in Malaysia were surveyed and data were collected from online distance learning students. 5-point Likert Scale survey questionnaire was used as an instrument to collect data based on the research framework. The research framework consists of five variables of attitude ( 5 items), subjective norm ( 5 
items), perceived behavior control ( 5 items), intention ( 7 items), and behavior ( 5 items). The questionnaire was distributed to the respondents through face to face surveys since the online survey response rate is low (Sekaran and Bougie, 2010). There was a total of 312 questionnaires distributed and 262 questionnaires were returned. This made up an $83.97 \%$ response rate and it is adequate to run structural equation modeling data analysis. Out of 262 returned questionnaires, 237 were completed and after deleting the outliers, 227 questionnaires were clean and available for analysis. Smartpls3 was used to perform multivariate data analysis for model evaluation and proposed hypotheses testing. The PLSSEM technique was adopted its capability to assess overall model measurement. In addition, it has the ability to evaluate the relationship between the latent constructs and their measures examination (Hair, Black, Babin, \& Anderson, 2010). PLS-SEM approach via PLS-SEM algorithm was utilized for measurement model assessment and later, evaluation of structural model by using bootstrapping and report the results.

\section{Data Analysis}

\section{Common Method Bias}

Common method bias one of the main issues when research in the management field is conducted. The issue will arise when the variance is not attributed to the constructs the measures supposed to represent in the study, but attributed to the measurement method instead. To inspect the bias of the measurement items in this study, Harman's single factor test was employed. After factor analysis of principal components was performed, the result of the principal factor showed $39.16 \%$ suggesting there was no issue of common method bias, since the principal factor did not hold the majority of variance explained. This is in line with Podsakoff \& Organ, (1986) who suggested that if the variance explained the percentage of principal components wasn't exceeding $50 \%$, there is no issue of common method bias.

\section{Measurement Model}

PLS-SEM Algorithm was applied in this study to measure the structural model and assess the construct measurement validity and reliability by using (Figure 1). For that reason, Hair, Hult, Ringle, and Sarstedt, (2017) propose that reliability and validity are the two essential criteria applied in PLS-SEM analysis to test the goodness outer model. As depicted in Table 1, the composite reliability ranged from 0.814 to 0.914 for the first-order constructs, therefore fulfilled the requirement of 0.70 and above (Hair et al., 2017). The result showed that average variance extracted (AVE) ranged from 0.573 to 0.691 which are all higher than of 0.50 , therefore showed convergent validity for all the latent constructs (Hair, Sarstedt, Ringle \& Mena, 2012). Items cross-loading were evaluated for further validation of the discriminant validity in this study. The result showed that all items' loadings were higher than their corresponding cross-loadings (Table 1). The presence of discriminant validity was further confirmed by assessing the Hetrotrait-Monotrait (HTMT) ratio of correlation developed by Henseler, Ringle \& Sarstedt (2015). The outcome of HTMT ratio analysis in Table 2 depicted that all ratios attained the HTMT criterion which was smaller than 0.9 (Henseler et al., 2015) and as a result, showed discriminant validity. Given that, this study proved the reliability and validity of the latent variables.

Therefore, based on the above measurement model analysis, this study has proven the reliability and validity of the latent variables (Hair, Hult, Ringle, and Sarstedt, 2014). 
Table 1: Construct Validity \& Reliability

\begin{tabular}{llllll}
\hline Item & Loading & CA & rho_A & CR & AVE \\
\hline ATT1 & 0.733 & 0.814 & 0.814 & 0.870 & 0.573 \\
ATT2 & 0.744 & & & & \\
ATT3 & 0.789 & & & & \\
ATT4 & 0.757 & & & & \\
ATT5 & 0.763 & & & & \\
BEH1 & 0.755 & 0.859 & 0.864 & 0.898 & 0.639 \\
BEH2 & 0.825 & & & & \\
BEH3 & 0.799 & & & & \\
BEH4 & 0.799 & & & & \\
BEH5 & 0.816 & & & & \\
INT1 & 0.814 & 0.914 & 0.918 & 0.931 & 0.660 \\
INT2 & 0.845 & & & & \\
INT3 & 0.856 & & & & \\
INT4 & 0.755 & & & & \\
INT5 & 0.752 & & & & \\
INT6 & 0.784 & & & & \\
INT7 & 0.872 & & & & \\
PBC1 & 0.803 & 0.888 & 0.890 & 0.918 & 0.691 \\
PBC2 & 0.853 & & & & \\
PBC3 & 0.821 & & & & \\
PBC4 & 0.867 & & & & \\
PBC5 & 0.810 & & & & \\
SN1 & 0.812 & 0.870 & 0.869 & 0.906 & 0.658 \\
SN2 & 0.837 & & & & \\
SN3 & 0.856 & & & & \\
SN4 & 0.779 & & & & \\
SN5 & 0.769 & & & & \\
\hline
\end{tabular}

ATT=Attitude, BEH=Behavior, INT=Intention PBC=Perceived Behavioral Control $S N=$ Social Norms $C A=$ Cronbach Alpha $C R=$ Composite Reliability

AVE=Average Variance Extracted

Table 2: Hetrotrait-Monotrait Ratio

\begin{tabular}{lllll}
\hline & ATT & BEH & INT & PBC \\
\hline ATT & & & & \\
BEH & 0.634 & & & \\
INT & 0.851 & 0.676 & & \\
PBC & 0.873 & 0.592 & 0.831 & \\
SN & 0.827 & 0.598 & 0.792 & 0.862 \\
\hline
\end{tabular}

Structural Model

The path coefficient and the R2 value (Hair et al., 2013) were used in this study to assess the structural model in this study. It used PLS bootstrapping 500 sub-samples to determine the significance of the path coefficients in the study. Table 3 shows the hypotheses test results, path coefficients, and t-values. In table 3 , hypothesis 1 predicts a positive relationship 
between attitude and intention and the result shows that there is a positive and significant influence of entrepreneurial education on attitude $(B=0.328, t=4.567)$; as a result, $H_{1}$ is supported. The result of hypotheses 2 also reveals a significant and positive relationship between social norms and intention $(B=0.342, t=4.339)$; thus supporting $H_{2}$. The hypotheses 3 result also shows that there is a positive and significant relationship present between perceived behavioral control and intention $(B=0.221, t=3.297)$; therefore $H_{3}$ is supported. Last, hypotheses 4 result reveals that there is a positive and significant relationship between intention and behavior $(~ B=0.606, t=14.405)$ and thus $H_{4}$ is supported. This study also tested the R2 of the endogenous construct of intention.

Table 3: Hypotheses Testing \& Results

\begin{tabular}{|c|c|c|c|}
\hline Path & Beta & $\begin{array}{l}\text { T- } \\
\text { value }\end{array}$ & $\begin{array}{l}\mathrm{P} \quad \text { Values } \\
\text { Decisions }\end{array}$ \\
\hline & & & 0.000 \\
\hline$H_{1}:$ ATT $->$ INT & 0.328 & 4.567 & $\begin{array}{l}\text { Supported } \\
0.000\end{array}$ \\
\hline $\mathrm{H}_{2} \quad \mathrm{SN}->\mathrm{INT}$ & 0.342 & 4.339 & $\begin{array}{l}\text { Supported } \\
0.001\end{array}$ \\
\hline$H_{3}:$ PBC $->$ INT & 0.221 & 3.297 & $\begin{array}{l}\text { Supported } \\
0.000\end{array}$ \\
\hline$H_{4}:$ INT $->B E H$ & 0.606 & 14.405 & Supported \\
\hline
\end{tabular}

\section{Discussion}

This study aims to establish an understanding of the direct effect of attitude, social norms, and perceived behavioral control intention and direct effect of intention on behavior to become social entrepreneurs among online distance learning students in Malaysia. An evaluation of previous studies on attitude, social norms, perceived behavioral control, intention, intention, and behavior were performed. With regards to the preliminary findings, the framework was developed and it has demonstrated that attitude, social norms, and perceived behavioral control have a positive and significant influence on intention, and intention has a positive and significant influence on behavior. The proposed model of this study is to empirically evaluate the direct influence of attitude, social norms, and perceived behavioral control on intention and direct influence of intention on behavior. To achieve this goal, the Partial Least Square (PLS) technique was adopted. Based on the above findings, it demonstrates that social norm has the strongest impact on the intention of the ODL students to become a social entrepreneur with a path coefficient of 0.342 . This shows how important the social norm elements in determining the intention of ODL students to become social entrepreneurs. The second strongest factor that has an impact on intention is the attitude, with the path coefficient of 0.328 . This proves that a person's attitude is very crucial in forming the entrepreneurial intention of ODL students. The third strongest factor that has an influence on intention is perceived behavioral control with the path coefficient of 0.221 . The ability of ODL students to perceive a given behavior can influence their intention and together can form the actual behavior. The result also shows that intention has a strong impact on the behavior of ODL students to become a social entrepreneur with the path coefficient 0.606. This shows how intention plays very important roles and influences the behavior of ODL students to become social entrepreneurs. This study reveals that the ODL institutions must play a role to emphasize attitude, social norms, and perceived behavioral control to develop 
the entrepreneurial intention which eventually will strengthen the behavior to become a social entrepreneur as their career.

\section{Conclusion}

This study aims at attitude, social norms, perceived behavioral control, intention, and behavior of students in online distance learning institutions in Malaysia to become a social entrepreneur. The results have revealed that direct influence of attitude, social norms, perceived behavioral control on intention and direct intention of behavior to become social entrepreneurs were statistically positive and significant. Entrepreneurship educators and researchers need to apply the approach where attitude, social norms, perceived behavioral control and intention can be boosted which eventually strengthen the behavior of ODL students to become social entrepreneur once they complete their study.

\section{References}

Abu-Saifan, S.(2012). Social entrepreneurship: definition and boundaries. Technology Innovation Management Review, 2(2).

Ajzen, I., \& Thomas, M. J. (1986). Prediction of goal-directed Behavior: Attitudes, intentions, and perceived behavioral control. Journal of Experimental Social Psychology, 22(5), 453-474. http://doi.org/10.1016/0022-1031(86)90045-4.

Ajzen, I. (1991). The theory of planned behavior. Organizational Behavior and Human Decision Processes, 50, 179-211.

Ajzen, I. (2002). Perceived behavioral control, self-efficacy, locus of control, and the theory of planned behavior. Journal of Applied Social Psychology, 32(4), 665-683.

Ajzen, I. (2005). Attitudes, personality and behavior. Second ed. Berkshire, England: McGrawHill.

Armitage, C. J., \& Conner, M.(2001). Efficacy of the theory of planned Behavior: A metaanalytic review. The British Journal of Social Psychology, 40(4), 471-499 http://doi.org/10.1348/014466601164939.

Barendsen, L., \& Gardner, H.(2004). Is the social entrepreneur a new type of leader? Leader to leader, (34), 43-50.

Cooper, S. Y., \& Park, J. S. (2008). The impact of incubator' organizations on opportunity recognition and technology innovation in new, entrepreneurial high-technology ventures. International Small Business Journal, 26(1), 27-56.

Dacanay, M. L. (2005). Social enterprise for a sustainable Asia. Alliance Magazine. Retrieved from http://www.alliancemagazine.org/node/1342.

Digital News Asia (2015). Malaysia unveils social enterprise blueprint, available at: https://www.digitalnewsasia.com/digital-economy/malaysia-unveils-social-enterpriseblueprint. (accessed 28 December 2019)

Ferreira, J. J., Raposo, M. L., Rodrigues, R. G., Dinis, A., \& Paço, A. D. (2012). A model of entrepreneurial intention: An application of the psychological and behavioral approaches. Journal of Small Business and Enterprise Development, 19(3), 424-440.

Hair, J. F., Black, W. C., Babin, B. J., \& Anderson, R. E. (2010). Multivariate data analysis ( $7^{\text {th }}$ Ed.).Englewood Cliffs: Prentice Hall.

Hair, J. F., Sarstedt, M., Ringle, C. M., \& Mena, J. A. (2012). An assessment of the use of partial least squares structural equation modeling in marketing research. Journal of the Academy of Marketing Science, 40(3), 414-433. 
Henseler, J., Ringle, C. M., and Sarstedt, M. (2015). A new criterion for assessing discriminant validity in variance-based structural equation modeling, Journal of the Academy of Marketing Science, 43(1): 115-135.

Hair, J. F., Hult, G. T. M., Ringle, C. M., \& Sarstedt, M. (2017). A primer on partial least squares structural equation modeling (PLS-SEM). Los Angeles: Sage Publication.

Kautonen, T., Van Gelderen, M., \& Tornikoski, E. T. (2013). Predicting entrepreneurial behaviour: a test of the theory of planned behaviour. Applied Economics, 45(6), 697707.

Krueger, N. F., \& Brazeal, D. V. (1994). Entrepreneurial potential and potential entrepreneurs. Entrepreneurship Theory and Practice, 18, 91-91.

Liñán, F., \& Chen, Y. W. (2009). Development and cross-cultural application of a specific instrument to measure entrepreneurial intentions. Entrepreneurship Theory and Practice, 33, 593-617.

Liñán, F. (2008). Skill and value perceptions: how do they affect entrepreneurial intentions? International Entrepreneurship and Management Journal, 4(3), 257-272.

Liñán, F., Rodríguez-Cohard, J. C., \& Rueda-Cantuche, J. M. (2011). Factors affecting entrepreneurial intention levels: a role for education. International Entrepreneurship and Management Journal, 7, 195-218.

MaGIC. (2018). About MaGIC, Malaysian Global Innovation \& Creativity Centre. Retrieved from https://mymagic.my/about/

Morrison \& Foerster. (2016). MoFo Impact- Legal and business insights for impact-driven change makers. Retrieved from https://impact.mofo.com/resources/socialenterprise-legislation-in-the-united-states-an-overview/

Mutsau. (2016). M. Attitudes of Students towards Entrepreneurship Education at Two Selected Higher Education Institutions in Botswana: A Critical Analysis and Reflection. Academic Journal of Interdisciplinary Studies, 5(2), 83-94

Omorede, A. (2014). Exploration of motivational drivers towards social entrepreneurship, Social Enterprise Journal. 10(3), $239-267$

Peng, Z., Lu, G., \& Kang, H. (2012). Entrepreneurial Intentions and Its Influencing Factors: A Survey of the University Students in Xi'an China. Creative Education, 3, 95-100

Remeikiene, R., Startiene, G., \& Dumciuviene, D. (2013). Explaining Entrepreneurial Intention of University Students: The Role of Entrepreneurial Education. Croatia International Conference, 2013, 299-307.

Renko, M., Kroeck, K. G., \& Bullough, A. (2012). Expectancy theory and nascent entrepreneurship. Small Business Economics. 39, 667-684.

Roberts, D., and Woods, C. (2005). Changing the world on a shoestring: The concept of social entrepreneurship, University of Auckland Business Review. 71, pp. 45-51.

Shane, S., \& Venkataraman, S. (2000). The promise of entrepreneurship as a field of research. Academy of Management Review, 25, 217-226.

Sekaran, U., \& Bougie, R. (2010), Research methods for business: A skill building approach. Wiley, London.

Sudipa, M., \& Damodharan, V. (2012). Students' attitude towards entrepreneurship: does gender matter in the UAE? Foresight 15(4): 278-293.

Wedayanti, N. P., Dan Giantari, I. (2016). Peran Pendidikan Kewirausahaan Dalam Memediasi Pengaruh Norma Subyektif Terhadap Niat Berwirausaha. E-Jurnal Manajemen Universitas Udayana. 5(1), 533-560. 
Yeoh, A. (2015). In Asia: challenges in the Malaysian social enterprise scene, available at http://asiafoundation.org/inasia/2015/08/26/challengesinthemalaysiansocialenterpris escen

Zainol, F. A., Daud, W. N. W., Abdullah, Z., \& Yaacob, M. R. (2014). Social Entrepreneurship Practice in Malaysia-The Case of Social NGO. International Journal of Academic Research in Business and Social Sciences, 4(12), 152. 